\title{
The nitrogen and energy metabolism of lactating cows given abomasal infusions of casein
}

\author{
BY F. G. WHITELAW, J. S. MILNE, E. R. ØRSKOV \\ AND J.S. SMITH \\ Rowett Research Institute, Bucksburn, Aberdeen AB2 9SB
}

(Received 14 February 1985 - Accepted 27 November 1985)

\begin{abstract}
1. Four cows in early lactation were given continuous infusion into the abomasum of $0,200,400$ or $600 \mathrm{~g}$ lactic casein/d according to a Latin-square design. Each period was of $14 \mathrm{~d}$ and the Latin square was followed by $7 \mathrm{~d}$ in which an infusion of $800 \mathrm{~g}$ glucose/d was given. The basal diet was given at a level which provided sufficient nitrogen and energy for $10 \mathrm{~kg}$ milk yield $/ \mathrm{d}$.

2. Infusion of casein resulted in significant increases in milk yield, milk $\mathbf{N}$ yield and milk energy yield; milk $\mathrm{N}$ increased progressively but milk energy reached a maximum at $400 \mathrm{~g}$ casein/d. Milk yields and composition when glucose was infused resembled those seen on the zero casein treatment.

3. N-balance measurements indicated a severe deficit $(-20 \mathrm{~g} / \mathrm{d})$ on the zero casein treatment and a progressive increase to $+7 \mathrm{~g} / \mathrm{d}$ as casein increased; $\mathrm{N}$ equilibrium was achieved at about $400 \mathrm{~g}$ casein/d. The regression of net productive $\mathrm{N}$ on $\mathrm{N}$ intake $(P<0.001)$ indicated that the efficiency of utilization of dietary $\mathrm{N}$ did not differ between treatments.

4. Heat production increased with increase in casein infused $(P<0.05)$ but remained a constant proportion of the metabolizable energy (ME) intake. Energy balances were negative and did not differ significantly between treatments but calculation of the protein and fat components indicated a threefold increase in body fat mobilization in response to the first increment of casein. Milk yield adjusted to zero energy balance was significantly related to ME intake $(P<0.001)$ but the efficiency of energy utilization was not affected by the level of casein infusion.

5 . The concentrations of glucose, $\beta$-hydroxybutyrate and non-esterified fatty acids in plasma did not differ between treatments but the concentration of urea in plasma increased markedly $(P<0.05)$ at the highest level of casein addition. Insulin concentrations increased and growth hormone decreased (both $P<0.05$ ) with increase in casein infusion.

6. The concentration of total amino acids (AA) in plasma increased up to $400 \mathrm{~g}$ casein $/ \mathrm{d}$ and then declined. Changes in concentration and in the ratio of essential:total AA indicated a very high extraction rate of essential AA at the lower levels of casein infusion.

7. The observed lactational responses are discussed in relation to the ratio of protein:energy in the absorbed nutrients. It is concluded that the primary response to casein was the correction of an AA deficit and that body fat mobilization was secondary and occurred in response to the high ratio of AA-N:energy in the infused casein.
\end{abstract}

Although there is now convincing evidence from a large number of studies that abomasal infusions of casein in lactating cows (Derrig et al. 1974; Spires et al. 1975; Ørskov et al. 1977; Rulquin, 1982) and goats (Farhan \& Thomas, 1977; Ranawana \& Kellaway, 1977 a, b; Gow et al. 1979) can lead to increases in milk yield and milk-protein yield, the precise mechanism of this response remains uncertain. Clark (1975) reviewed the early literature on this topic and concluded that the response to casein could arise (a) through the provision of essential amino acids (EAA) which may be limiting in the basal mixture reaching the duodenum, or (b) by the provision of additional glucogenic substrates which might allow increased glucose and lactose synthesis or (c) by an alteration in the hormonal status of the animal. Subsequent work however has failed to establish any one of these as the prime factor in the initiation of the casein response (Schwab et al. 1976; Clark et al. 1977; Oldham et al. 1984) and it seems likely that interactions between the various factors play an important part in determining the final outcome (Oldham, 1981; Bines \& Hart, 1982; Mepham, 1982; Oldham \& Lindsay, 1983).

Possibly the most significant advance in recent years has been the demonstration by Ørskov et al. (1977) that abomasal additions of casein to cows in early lactation resulted in an 
increase in plasma levels of non-esterified fatty acids and in the calculated negative energy balance. These workers postulated that casein infusions, possibly through the provision of some limiting amino acid(s), had the effect of facilitating the mobilization of body fat in support of milk production and showed that this response was greatest when energy intake was restricted to ensure some dependence on body energy stores. In support of this hypothesis the authors noted that the greatest responses to casein appeared to occur when animals were drawing on body reserves, either in early lactation or as a result of some degree of dietary restriction (Derrig et al. 1974; Ranawana \& Kellaway, 1977a,b). The increases in milk yield and in the daily yields of protein and fat in response to casein infusion in the experiments of Ørskov et al. (1977) were greater than any previously reported, and in common with many reports in the literature the infusion of glucose had no effect on milk yield or body fat mobilization, suggesting that the glucogenic effect of casein was probably of minor importance

In a later study, Ørskov et al. (1981) showed that increases in milk yield and in body fat mobilization and live-weight loss similar to those achieved with abomasal infusions of casein were obtained when a relatively undegradable protein, fish meal, was substituted for groundnut meal in the diet of cows in early lactation. Similar findings indicating increased weight loss or body fat mobilization have been reported in practical feeding trials with dairy cows (Sparrow et al. 1973) and lactating ewes (Robinson et al. 1974, 1979) when the dietary intake of protein was increased. In all these studies, however, the evidence for an increase in the mobilization of body tissue has been obtained indirectly, by calculation from metabolizable energy (ME) intake and milk energy yields or from changes in plasma constituents or live weight. With the exception of a rather inconclusive study by Trigg et al. (1983) no direct calorimetric measurements appear to have been made of the effect of casein infusions on energy metabolism or on protein-energy interrelations in lactation. The present paper reports such observations for the dairy cow and outlines a possible mechanism of the response to casein. A preliminary report of these findings has been given elsewhere (Whitelaw et al. 1985).

\section{MATERIALS AND METHODS}

\section{Animals and management}

Four Ayrshire cows in the second or third lactation were used. During the last 6 weeks of pregnancy they were allowed ad lib. a complete mixed diet based on ammonia-treated straw and sugar-beet pulp. Within $36 \mathrm{~h}$ of parturition each animal had an infusion catheter of vinyl tubing inserted into the mid-lateral wall of the abomasum under paravertebral anaesthesia. The catheters were similar to those described by MacLeod et al. (1982) and were exteriorized via a stab wound ventral to the transverse processes of the fifth lumbar vertebra. In all animals recovery from surgery was uneventful and both appetite and milk production returned to normal levels within $2 \mathrm{~d}$. The experimental treatments were introduced, on average, $20 \mathrm{~d}$ after calving (range 16-25 d) when the mean live weight was 469 (SE 9) kg.

\section{Design and treatments}

A $4 \times 4$ Latin-square design was used in which the treatments were (1) basal diet with water infusion into the abomasum, (2) basal diet plus $200 \mathrm{~g}$ casein/d infusion, (3) basal diet plus $400 \mathrm{~g}$ casein/d and (4) basal diet plus $600 \mathrm{~g}$ casein/d. In each animal these treatments were preceded by a $5 \mathrm{~d}$ preliminary period in which the diet was restricted (see p. 539) and a daily infusion of 25 litres water was given into the abomasum. In addition, the main Latin-square sequence of treatments was followed by a final period of $7 \mathrm{~d}$ in which an abomasal infusion 
of $800 \mathrm{~g}$ glucose/ $\mathrm{d}$ was given; this was calculated to provide the same daily energy intake as the $600 \mathrm{~g} / \mathrm{d}$ level of casein. The casein solutions were made up freshly each day from a stock solution containing $100 \mathrm{~g}$ lactic casein $/ \mathrm{kg}$ and $5 \cdot 3 \mathrm{~g}$ sodium carbonate $/ \mathrm{kg}$ (MacLeod et al. 1982) which was kept refrigerated at $4^{\circ}$. The required daily amounts of this solution were made up to 25 litres in water and the infusions were made with a peristaltic pump (Watson-Marlow Ltd, Falmouth, Cornwall) set to deliver 25 litres in $23 \mathrm{~h}$.

Each of the main treatment periods was of $14 \mathrm{~d}$ duration of which days 2-7 inclusive were used for collection of faeces and urine and days 9-13 inclusive were used for measurement of gaseous exchange within respiration chambers. Blood sampling took place over $24 \mathrm{~h}$ on day 14. Animals were weighed at the start and thereafter on day 8 and on day 14 of each period. No measurements of digestibility or of respiratory exchange were made during the glucose treatment period.

\section{Diet and feeding}

The basal diet was a mixture $(\mathrm{g} / \mathrm{kg})$ of ammonia-treated barley straw 550 , unmolassed sugar-beet pulp 300 , rolled barley 60 , molasses 60 , urea 10 , proprietary dairy-cow mineral-vitamin supplement 18 , and sodium sulphate 2 . The ammonia-treated straw was prepared as described by $\varnothing$ rskov et al. (1983); it contained on average $16.6 \mathrm{~g} \mathrm{~N} / \mathrm{kg}$ dry matter (DM) and was ground through a $40 \mathrm{~mm}$ hammermill before inclusion in the basal mixture.

The estimated metabolizable energy (ME) content of the diet was $10.5 \mathrm{MJ} / \mathrm{kg} \mathrm{DM}$ and it was offered ad lib. from calving until the start of the $5 \mathrm{~d}$ preliminary period. Intake was then restricted to provide sufficient energy for maintenance plus $10 \mathrm{~kg}$ milk yield. Maintenanıe was taken as $510 \mathrm{~kJ} \mathrm{ME} / \mathrm{kg}$ body-weight ${ }^{0.75}$ (Moe et al. 1971) and the requirement for milk production as $4.94 \mathrm{MJ} \mathrm{ME} / \mathrm{kg}$ milk (Ministry of Agriculture, Fisheries and Food, 1975). The animals received their ration as two equal meals at 07.30 and 15.30 hours. Re-adjustment of intake on the basis of body-weight was made at the end of this $5 \mathrm{~d}$ period and then remained constant throughout the experiment.

The $\mathrm{N}$ content of the diet was $21.8 \mathrm{~g} / \mathrm{kg} \mathrm{DM}$ and it was formulated to provide, at the restricted level of intake, sufficient rumen-degradable nitrogen (RDN) and just sufficient undegradable $N$ (UDN) to meet the requirements for maintenance plus $10 \mathrm{~kg}$ milk production/d (Agricultural Research Council, 1984). The UDN derived from ammoniatreated straw was assumed to be unavailable. On this basis the diet provided $1.34 \mathrm{~g} \mathrm{RDN} / \mathrm{MJ} \mathrm{ME}$ and $0.22 \mathrm{~g} \mathrm{UDN} / \mathrm{MJ} \mathrm{ME}$. The maintenance requirement for $\mathrm{N}$ was taken as $350 \mathrm{mg} / \mathrm{kg}$ body-weight ${ }^{0 \cdot 75}$ (Agricultural Research Council, 1984). The casein contained, on a DM basis, $159 \mathrm{~g} \mathrm{~N} / \mathrm{kg}$ and $23.91 \mathrm{MJ} / \mathrm{kg}$.

\section{Milk recording and analysis}

The cows were milked twice daily and separate samples from each milking were retained for analysis of $\mathrm{N}$, fat and total solids. Additional samples were obtained from each animal at the last four milkings in each period, bulked in proportion to milk yield and centrifuged at $3000 \mathrm{~g}$ for $15 \mathrm{~min}$ to separate the fat. The fat and skimmed milk components were then stored separately at $-20^{\circ}$ to await analysis.

\section{Digestibility measurements}

The animals were held in metabolism stalls and separation of urine from faeces was achieved with a modification of the collection system described by Cowan et al. (1981 a) using a delivery chute of light-weight polyethylene tubing (layflat tubing; Transatlantic Plastics Ltd, Isle of Wight) attached by adhesive to the animal's rump. Almost perfect quantitative collections of urine were obtained by this method. The urine was delivered into a 40 litre 
polyethylene bin containing $500 \mathrm{ml}$ sulphuric acid $(100 \mathrm{~g} / \mathrm{kg})$ as preservative. Faeces and urine were weighed and subsampled daily for analysis.

Collections of faeces and urine were made over $6 \mathrm{~d}$ during the 1 st week of each period. This procedure was adopted because difficulties had been experienced in separating urine and faeces in the confined space of the respiration chambers, which had been designed originally for steers. The relatively short adaptation period between the start of each treatment and the collections of faeces and urine was considered adequate in view of the fact that the basal diet and intake level remained constant between treatments, and casein infused into the abomasum is known to have a very high digestibility (Blaxter \& Martin, 1962). It was known also from earlier work that milk yield responds very rapidly to abomasal additions of casein (Ørskov et al. 1977) with the major changes being evident within $24 \mathrm{~h}$ (see also p. 541).

\section{Calorimetric measurements}

Measurements of oxygen uptake and carbon dioxide and methane output were made over $5 \mathrm{~d}$ periods in the confinement respiration chambers described by Blaxter et al. (1972). Heat production was calculated from the respiratory exchange using the factors of Brouwer (1965). All animals were trained to confinement and to the routine procedures of the chamber operations before parturition.

\section{Blood and rumen sampling}

Blood samples were obtained from each animal via an indwelling catheter inserted in the jugular vein at 08.00 hours on the morning of removal from the respiration chamber. Samples were taken into heparinized tubes and immediately centrifuged to separate plasma which was stored at $-20^{\circ}$. Sampling times were $10.00,14.00,18.00,22.00,02.00,06.00$ and 10.00 hours and each sample was later analysed for glucose, urea, $\beta$-hydroxybutyrate, free amino-N, non-esterified fatty acids (NEFA), insulin and growth hormone (GH). In addition, the seven samples obtained on each sampling date were bulked to provide a composite sample for each animal for the assay of individual amino acids (AA).

Samples of rumen fluid were obtained from each animal in periods 3 and 4 only, using a stomach tube. The samples were frozen immediately and were held at $-20^{\circ}$ until analysed for individual volatile fatty acids (VFA).

\section{Analytical methods}

The analysis of $\mathrm{N}$ in milk, feeds, faeces and urine was by the automated Kjeldahl method described by Davidson $e t$ al. (1970). Milk fat was determined by the Gerber method and total solids in milk by the method of Ling (1944). Feeds and faeces were analysed for DM by oven drying at $100^{\circ}$ for $48 \mathrm{~h}$ and for organic matter $(\mathrm{OM})$ by ashing at $580^{\circ}$. Gross energy in feeds, faeces and urine was determined in an automated adiabatic calorimeter (A. Gallenkamp \& Co. Ltd, London); gross energy of milk was calculated from the yield of milk corrected to a fat content of $40 \mathrm{~g} / \mathrm{kg}$ (fat-corrected milk; FCM) using an energy value of $3 \cdot 184 \mathrm{MJ} / \mathrm{kg}$ (Gaines \& Overman, 1938).

Automated methods (Technicon Instrument Co. Ltd, Basingstoke, Hampshire) were used to analyse plasma for glucose (Trinder, 1969), urea (Marsh et al. 1965), $\beta$-hydroxybutyrate (Zivin \& Snarr, 1973) and free-amino groups (Palmer \& Peters, 1969). The concentrations of insulin and of GH in plasma were determined by the radioimmunoassay techniques of Bassett \& Thornburn (1971) and Galbraith \& Chesworth (1977) respectively.

The NEFA in plasma were analysed by gas-liquid chromatography of their methyl esters using a $25 \mathrm{~m} \times 1.2 \mathrm{~mm}$ capillary column coated with CP Sil 5 (Chrompack Ltd, London). Total lipids were first extracted with chloroform-methanol and then esterified with 
diazomethane as described by Schlenk \& Gellerman (1960). The resulting methyl esters were separated from other lipids by thin-layer chromatography and the esters extracted from the adsorbent with diethyl ether before chromatography.

Plasma samples for amino acid analysis were deproteinized with sulphosalicylic acid (SSA) after the addition of nor-leucine as an internal standard. The SSA was removed by passage through a cation-exchange resin and the amino acids subsequently collected in $2 \mathrm{M}$-ammonia solution. Ammonia was removed by rotary evaporation and the samples analysed on a Chromaspek amino acid analyser (Rank Hilger Ltd, Kent) using a $350 \times 3 \mathrm{~mm}$ stainless-steel column packed with a cross-linked cation-exchange resin of bead size $6-7 \mu \mathrm{m}$.

The $\mathrm{C}_{2}-\mathrm{C}_{6}$ VFA in rumen fluid were assayed by gas-liquid chromatography using a commercial column packing (SP 1200; Supelco Inc., Bellefonte, USA) and a flame-ionization detector, essentially as described by Ottenstein \& Bartley (1971).

\section{Statistical analysis}

The main effects of period and treatment in the Latin-square layout were determined by analysis of variance and the treatment effects were examined also for the presence of linear and quadratic trends. Since some of the measurements examined showed significant period effects the values obtained for the glucose infusion period, introduced at the end of the Latin square, could not be compared directly with the other four treatments. In most cases, values obtained with glucose were similar to those on the control (zero-casein) treatment and they are included in the tables where appropriate purely for comparative purposes, without further statistical treatment.

\section{RESULTS}

\section{Milk yield and composition}

All animals responded very rapidly to the infusion of casein, a change in infusion level at 10.00 hours usually being reflected in some change in milk yield at 16.30 hours and the changes in most cases being complete by 07.30 hours next day. The comparison of treatment effects was therefore based on mean milk yields recorded over the full $14 \mathrm{~d}$ of each period.

Mean daily milk yield increased from $13.0 \mathrm{~kg} / \mathrm{d}$ when no casein was given to over $17 \mathrm{~kg} / \mathrm{d}$ at the highest level of casein infusion (Table 1); this represented a proportionate increase in milk yield of 0.32 and was highly significant $(P<0.01)$. The fat, $\mathrm{N}$ and total solids content of the milk did not differ significantly between treatments although there was a tendency for fat concentrations to decrease and $\mathrm{N}$ to increase with increasing amounts of casein infused $(P<0.05)$. The yield of FCM, and hence of milk energy, appeared to reach a maximum at the $400 \mathrm{~g} / \mathrm{d}$ level of casein infusion and this was true also of milk fat yield. In contrast the daily yields of both $\mathrm{N}$ and total solids in milk continued to increase when the casein infusion increased to $600 \mathrm{~g} / \mathrm{d}(P<0.01$ and $P<0.05$ respectively). The mean concentration of urea in the composite skim-milk samples obtained at the end of each period ranged from 192 to $306 \mathrm{mg}$ urea/l as casein infusions increased; urea- $\mathrm{N}$ as a proportion of total milk $N$ was thus small, ranging from 0.018 to 0.027 over the four treatments. Despite the apparent plateau in the response to casein by some of the indices examined no significant quadratic trends were noted for any of them.

When the infusion of casein was replaced by an infusion of $800 \mathrm{~g}$ glucose $/ \mathrm{d}$ at the end of period 4, there was a decrease in the yield of milk and milk constituents to values similar to or less than those recorded on the zero-casein treatment (Table 1).

\section{Digestibility and $N$ metabolism}

The mean apparent digestibility coefficients of DM and OM did not differ significantly between treatments (Table 2). Casein-N given by abomasal infusion was almost wholly 
Table 1. The effects of abomasal infusions of casein or glucose on milk yield, fat-corrected milk yield (FCM), milk composition and the daily yields of milk constituents in dairy cows

(Each value is the mean of four observations)

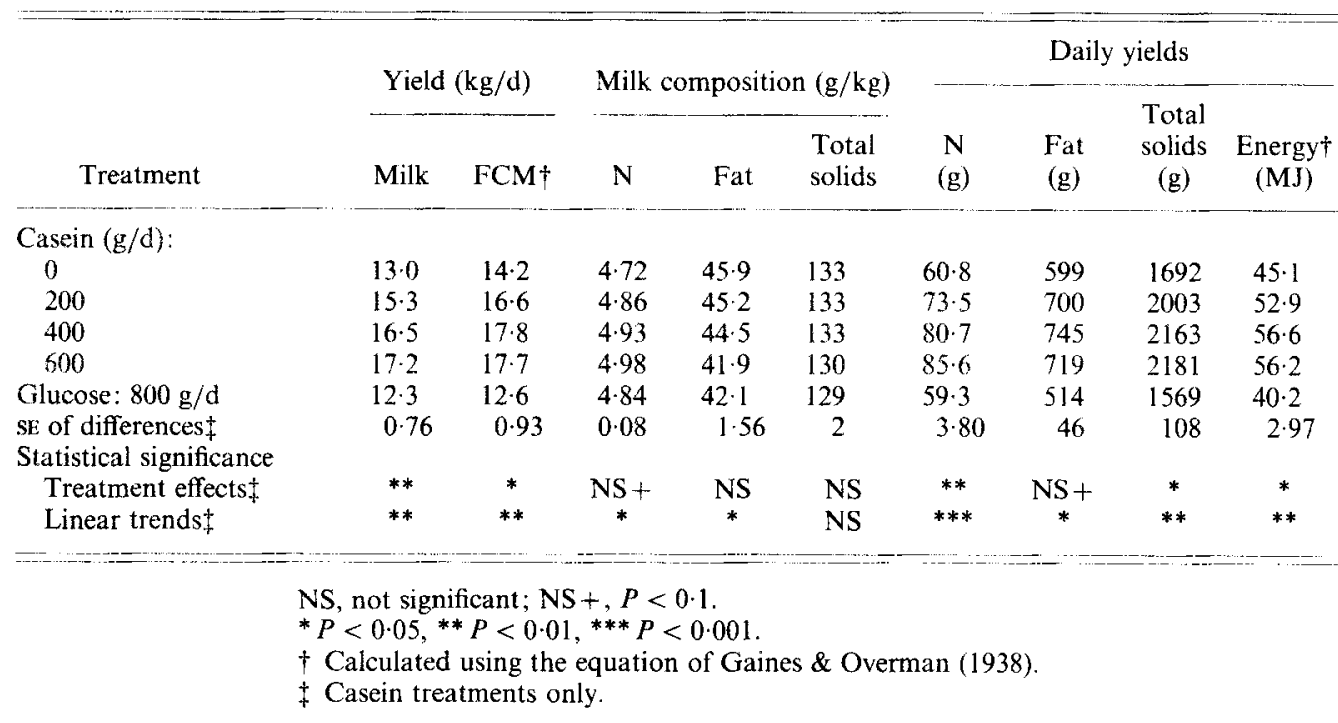

digested, as illustrated by the fact that increments of $\mathrm{N}$ amounting to $86 \mathrm{~g} / \mathrm{d}$ at the highest level of supplementation increased the excretion of $N$ in faeces by less than $4 \mathrm{~g} / \mathrm{d}$. The urinary excretion of $\mathrm{N}$ showed a highly significant linear trend $(P<0.01)$ but a significant effect of treatment was apparent only between the highest level of casein infusion and the others $(P<0 \cdot 05)$. As noted previously, milk $\mathrm{N}$ increased progressively with successive additions of casein $(P<0.01)$. As a result of these changes in the partition of daily $N$ intake, the retention of $\mathrm{N}$ in body tissue also increased progressively from $-20 \mathrm{~g} / \mathrm{d}$ on the casein-free treatment to $+7 \mathrm{~g} / \mathrm{d}$ at the highest level of casein infusion $(P<0.01)$. No significant quadratic component was detected in the response to casein of any of the measurements examined in Table 2.

A highly significant linear relation $(P<0.001)$ was observed between the daily intake of $\mathrm{N}$ and the net utilization of $\mathrm{N}$ for productive purposes. Separate regressions established either within treatment groups or within animals did not differ significantly one from the other within sets and the relation was best described by the composite regression shown in Fig. 1:

$$
Y=0.64(\text { SE } 0.06) X-892 \text {, }
$$

where $Y$ is productive $\mathrm{N}$ (milk $\mathrm{N}$ plus retained $\mathrm{N}$ ) and $X$ is daily $\mathrm{N}$ intake (dietary $\mathrm{N}+\operatorname{infused} \mathrm{N}$ ), both expresed as $\mathrm{mg} \mathrm{N} / \mathrm{kg}$ body-weight ${ }^{075}$ per $\mathrm{d}$. The residual standard deviation (RSD) of this relation was $74 \mathrm{mg} \mathrm{N} / \mathrm{kg}$ body-weight $\mathrm{t}^{0.75}$ per d, equivalent to 0.11 of the mean value.

\section{Energy metabolism}

Gross energy intake increased by $4.3 \mathrm{MJ}$ for each increment of casein giving a total overall increase of $13 \mathrm{MJ}$, or 0.08 of the basal intake of energy (Table 3). As there were no indications of significant treatment effects or trends in the losses of energy in faeces, urine or methane, the increase in gross energy intake was reflected in significant changes in $\mathrm{ME}$ intake with increasing amounts of casein infused $(P<0.05)$. Heat production also showed 


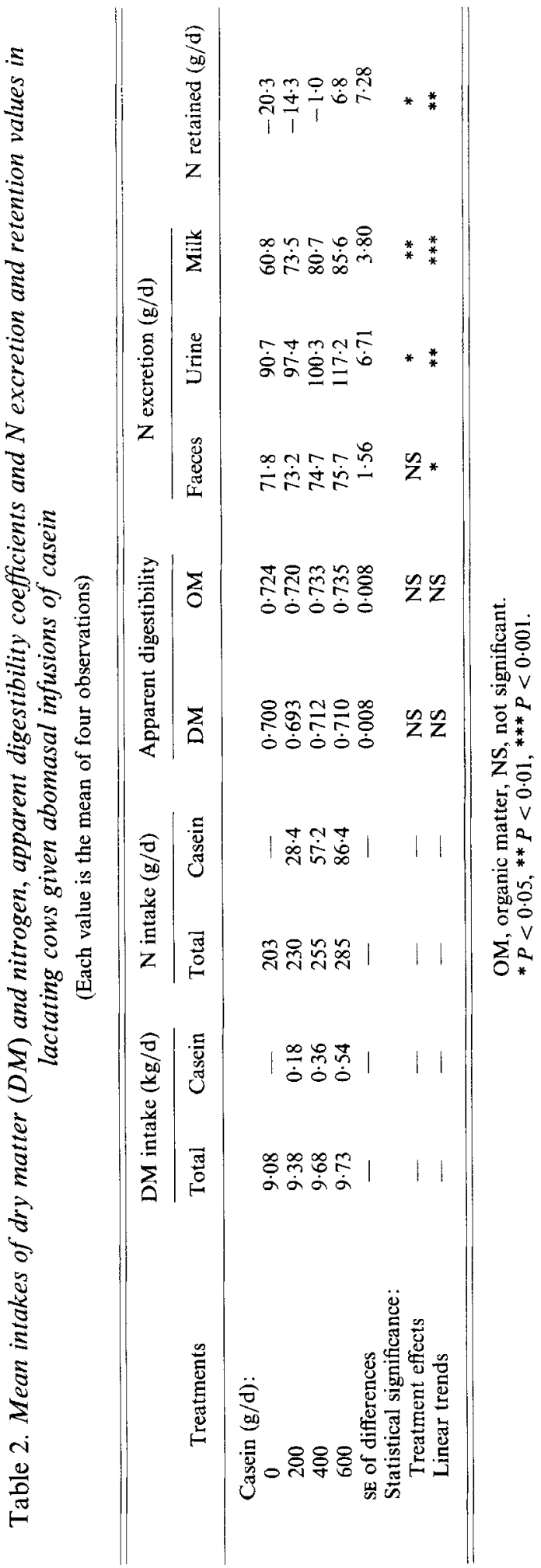




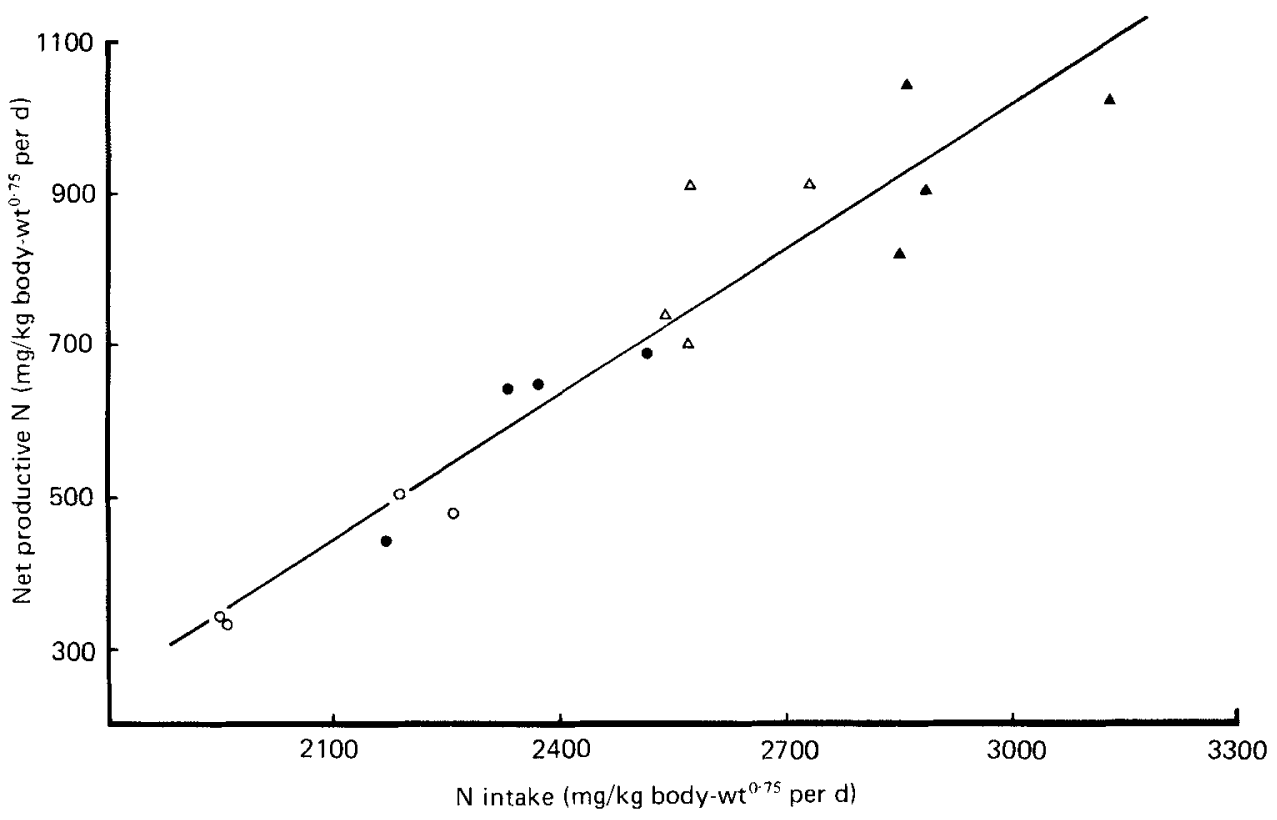

Fig. 1. The relation between net productive nitrogen (milk $\mathrm{N}+$ retained $\mathrm{N}$ ) and $\mathrm{N}$ intake (dietary $\mathrm{N}+$ casein $\mathrm{N}$ ), both expressed as $\mathrm{mg} / \mathrm{kg}$ body-weight $0^{75}$ per $\mathrm{d}$, in lactating cows given abomasal infusions of casein. The levels of casein infused were $0(\mathrm{O}), 200(\triangle), 400(\triangle)$ and $600(\Delta) \mathrm{g} / \mathrm{d}$. The regression equation was

$$
Y=0.64 X-892 \quad(P<0.001, \text { see p. 542). }
$$

Table 3. Mean daily intakes of energy and partition of energy losses in lactating cows given abomasal infusions of casein

(Each value is the mean of four observations)

\begin{tabular}{|c|c|c|c|c|c|c|c|c|c|}
\hline \multirow[b]{2}{*}{ Treatment } & \multicolumn{2}{|c|}{$\begin{array}{c}\text { Energy intake } \\
(\mathrm{MJ} / \mathrm{d})\end{array}$} & \multicolumn{7}{|c|}{ Energy metabolism $(\mathrm{MJ} / \mathrm{d})$} \\
\hline & Total & Casein & Faeces & Urine & Methane & Metabolized & Milk & Heat & Retention \\
\hline \multicolumn{10}{|l|}{ Casein $(g / d)$ : } \\
\hline 0 & 168 & - & $50 \cdot 5$ & $5 \cdot 0$ & $14 \cdot 4$ & $98 \cdot 0$ & $45 \cdot 1$ & $59 \cdot 2$ & $-6 \cdot 3$ \\
\hline 200 & 174 & $4 \cdot 3$ & $52 \cdot 3$ & 5.6 & $14 \cdot 7$ & $101 \cdot 9$ & $52 \cdot 9$ & $61 \cdot 8$ & $-12 \cdot 8$ \\
\hline 400 & 180 & $8 \cdot 6$ & $48 \cdot 7$ & $5 \cdot 2$ & $15 \cdot 4$ & $110 \cdot 3$ & $56 \cdot 6$ & $65 \cdot 2$ & $-11 \cdot 4$ \\
\hline 600 & 182 & $12 \cdot 9$ & $48 \cdot 4$ & $5 \cdot 9$ & $14 \cdot 7$ & $112 \cdot 7$ & $56 \cdot 2$ & $64 \cdot 4$ & $-7 \cdot 9$ \\
\hline SE of differences & - & - & $3 \cdot 50$ & $0 \cdot 40$ & 0.46 & $3 \cdot 40$ & 2.97 & $1 \cdot 44$ & $5 \cdot 20$ \\
\hline \multicolumn{10}{|l|}{ Statistical significance: } \\
\hline Treatment effects & - & 一 & NS & NS & NS & $*$ & $*$ & $*$ & NS \\
\hline Linear trends & - & - & NS & NS & NS & $* *$ & $* *$ & $* *$ & NS \\
\hline
\end{tabular}

NS, not significant.

$* P<0.05, * * P<0.01$.

a significant increase with increasing amounts of casein up to $400 \mathrm{~g} / \mathrm{d}(P<0.05)$ but this was in line with the increase in ME such that heat production as a proportion of $\mathrm{ME}$ remained constant across treatment groups, with an overall mean value of 0.60 (SE 0.01). Mean energy retention was negative for all treatment groups, indicating a considerable mobilization of body energy reserves in support of milk secretion. These measurements 


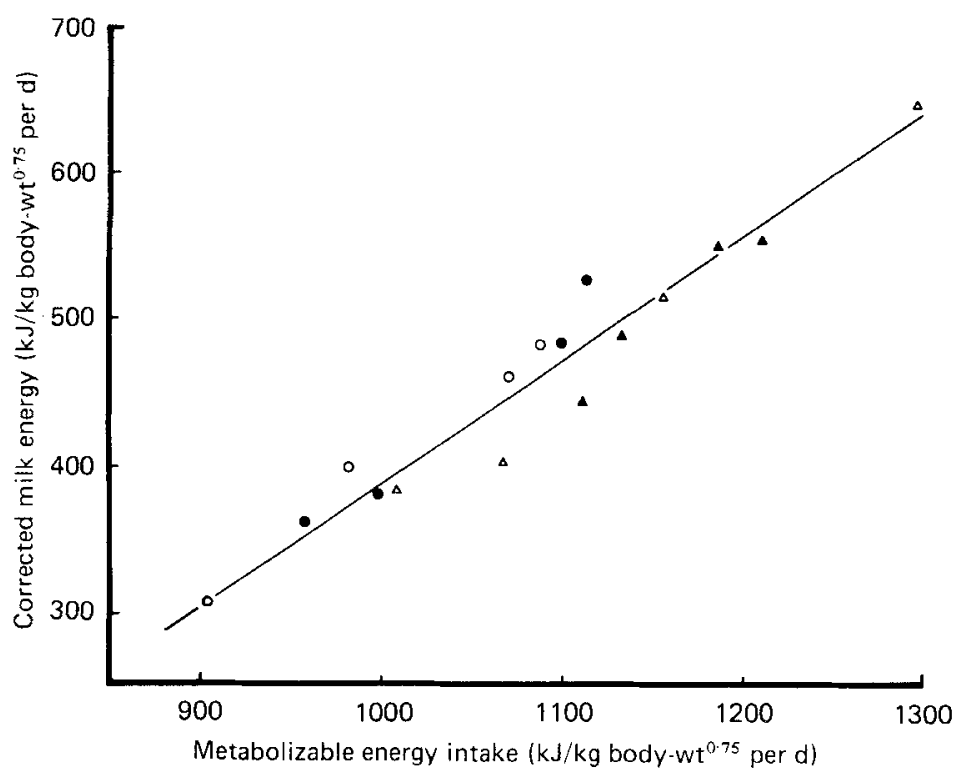

Fig. 2. The relation between corrected milk energy yield (see below) and metabolizable energy intake, both expressed as $\mathrm{kJ} / \mathrm{kg}$ body-weight ${ }^{0 \cdot 75}$ per $\mathrm{d}$, in lactating cows given infusions of casein into the abomasum. The levels of casein infused were $0(\bigcirc), 200(\bigcirc), 400(\triangle)$ and $600(\Delta) \mathrm{g} / \mathrm{d}$. The regression equation was

$$
Y=0.84 X-451 \quad(P<0.001, \text { see below }) .
$$

however were highly variable and did not differ significantly between treatments. Estimates of energy retention of course contain the cumulative errors of all other measurements and in the present experiment these estimates were subject also to highly significant period effects $(P<0.001$; see p. 548). The mean energy retention reported for the zero-casein treatment in particular was heavily weighted by a single large negative observation recorded in period 1 ; when this observation was omitted mean energy retention for this treatment group was positive, at 1.40 (SE 1.78$) \mathrm{MJ} / \mathrm{d}$.

When related to the energy supplied as casein, the incremental responses in milk-energy yield represent apparent efficiency factors of $1.84,1.34$ and 0.86 for the 200,400 and $600 \mathrm{~g} / \mathrm{d}$ infusion levels respectively. This calculation however ignores the contribution made to milk-energy yield by mobilized body tissue which accounted, for example, for 0.4 of milk energy at the $200 \mathrm{~g}$ casein/d level. In order to examine the relation between milk energy and $\mathrm{ME}$ intake in the absence of change in body-energy stores, milk-energy yields were adjusted to zero-energy balance using the factors proposed by the Agricultural Research Council (1980). Energy lost from the body was assumed to be utilized for milk synthesis with an efficiency of 0.84 and energy gained was taken to be deposited with an efficiency equal to 0.95 of the efficiency observed for lactation. The corrected milk energy, $\mathrm{YE}(\mathrm{C})$ (Agricultural Research Council, 1980), was thus $\mathrm{YE}(\mathrm{C})=$ milk energy $+(0 \cdot 84 \times$ negative retention $)+(1.05 \times$ positive retention $)$. When this expression was used as the dependent variable $(Y)$ significant linear relations were observed between milk energy and ME intake $(X)$, both expressed as $\mathrm{kJ} / \mathrm{kg}$ body-weight $\mathrm{t}^{0 \cdot 75}$ per $\mathrm{d}$. Seperate regressions established either within treatment groups or within animals did not differ significantly one from the other within sets and the data were best described by the linear relation $(P<0.001)$ shown in Fig. 2. The equation was

$$
Y=0.84(\mathrm{SE}, 0 \cdot 06) X-451
$$


Table 4. Effects of abomasal infusion of casein or glucose on the concentration of certain metabolites in jugular plasma of lactating cows

(Each value is the mean of four observations and each of these in turn was the mean value for seven plasma samples obtained over a 24 h period)

\begin{tabular}{|c|c|c|c|c|c|c|c|}
\hline Treatment & $\begin{array}{c}\text { Glucose } \\
(\mathrm{mg} / \mathrm{l})\end{array}$ & $\begin{array}{c}\beta \text {-hydroxybutyrate } \\
(\mathrm{mmol} / \mathrm{l})\end{array}$ & $\begin{array}{l}\text { Non-esterified } \\
\text { fatty acids } \\
(\mu \mathrm{g} / \mathrm{ml})\end{array}$ & $\begin{array}{l}\text { Urea } \\
(\mathrm{mg} / 1)\end{array}$ & $\begin{array}{c}\text { Free } \\
\text { amino-nitrogen } \\
(\mathrm{mg} / 1)\end{array}$ & $\begin{array}{l}\text { Insulin } \\
(\mu \mathrm{U} / \mathrm{ml})\end{array}$ & $\begin{array}{l}\text { Growth } \\
\text { hormone } \\
(\mathrm{ng} / \mathrm{ml})\end{array}$ \\
\hline \multicolumn{8}{|l|}{ Casein $(\mathrm{g} / \mathrm{d})$ : } \\
\hline 0 & 627 & $2 \cdot 43$ & $66 \cdot 9$ & 222 & $23 \cdot 7$ & 7.7 & $10 \cdot 0$ \\
\hline 200 & 647 & $1 \cdot 87$ & $81 \cdot 2$ & 248 & $26 \cdot 4$ & $7 \cdot 4$ & $8 \cdot 2$ \\
\hline 400 & 654 & 1.94 & $108 \cdot 5$ & 259 & $26 \cdot 0$ & $9 \cdot 4$ & $6 \cdot 4$ \\
\hline 600 & 670 & 1.43 & $76 \cdot 8$ & 332 & $24 \cdot 6$ & $11 \cdot 4$ & $7 \cdot 0$ \\
\hline Glucose: $800 \mathrm{~g} / \mathrm{d}$ & 719 & 0.75 & $19 \cdot 5$ & 168 & $26 \cdot 2$ & $12 \cdot 2$ & $6 \cdot 5$ \\
\hline SE of differences ${ }^{\dagger}$ & 26 & $0 \cdot 55$ & $23 \cdot 0$ & 26 & 0.5 & 1.05 & $1 \cdot 00$ \\
\hline \multicolumn{8}{|l|}{$\begin{array}{l}\text { Statistical } \\
\text { significance: }\end{array}$} \\
\hline Treatment effects $\nmid$ & NS & NS & NS & $*$ & $* *$ & * & * \\
\hline Linear trends $\dagger$ & NS & NS & NS & NS & NS & $* *$ & $*$ \\
\hline
\end{tabular}

NS, not significant.

$* P<0.05, * * P<0.01$.

$\dagger$ Casein treatments only.

and the regression had a RSD of $22.6 \mathrm{~kJ} / \mathrm{kg}$ body-weight $0^{0.75}$ per d, equivalent to 0.05 of the mean value. The intercept of this equation provides an estimate of $535 \mathrm{~kJ} / \mathrm{kg}$ body-weight $t^{\cdot \cdot 75}$ per $d$ for the maintenance energy requirement.

\section{Plasma analyses}

The effects of casein and glucose infusions on the concentrations of certain plasma metabolites are given in Table 4 . Of the three energy-yielding constituents examined, glucose, $\beta$-hydroxybutyrate and NEFA, none showed any significant change in response to the infusion of graded amounts of casein. Plasma glucose and $\beta$-hydroxybutyrate concentrations were within normal ranges except for one animal given the casein-free treatment in period 1, in which a large negative energy deficit was associated with $\beta$-hydroxybutyrate values of $5.65 \mathrm{mmol} / \mathrm{l}$ and plasma glucose values of $527 \mathrm{mg} / \mathrm{l}$. This was the only indication in this experiment of a possible incipient ketosis but the biochemical findings were not accompanied by any clinical symptoms of the condition and ketones were absent from milk and urine.

The concentrations of both urea and free amino- $\mathrm{N}$ in plasma showed significant changes in response to the additions of casein, although the nature of the responses differed. For urea no significant change was seen until casein infusion exceeded $400 \mathrm{~g} / \mathrm{d}$ when plasma concentrations increased by approximately one-third $(P<0.05)$; for free-amino- $\mathrm{N}$, in contrast, there was a highly significant increase in concentration in response to the first increment of casein $(P<0.01)$, plasma levels remained elevated when casein infusion was $400 \mathrm{~g} / \mathrm{d}$ and then decreased significantly at the highest level of casein supplementation. The quadratic component of this response was highly significant $(P<0.001)$. The concentrations of both insulin and $\mathrm{GH}$ in plasma showed significant linear trends in response to treatment. Insulin increased progressively $(P<0.01)$ with increasing amounts of casein whereas $\mathrm{GH}$ concentrations showed a decrease as casein increased $(P<0.05)$. 
Table 5. Mean concentrations of free amino acids $(A A ; m m o l / l)$ in jugular plasma of lactating cows given abomasal infusions of casein or glucose

(Each value is the mean of four observations, each of which represented a composite of seven separate samples obtained over a $24 \mathrm{~h}$ period)

\begin{tabular}{|c|c|c|c|c|}
\hline Treatment & $\begin{array}{c}\text { Total } \\
\text { AA }\end{array}$ & $\begin{array}{c}\text { Essential } \\
\text { AA }_{+}^{+}\end{array}$ & $\begin{array}{c}\text { Non-essential } \\
\text { AA }\end{array}$ & $\begin{array}{c}\text { Essential } \\
\text { AA: total AA }\end{array}$ \\
\hline \multicolumn{5}{|l|}{ Casein $(\mathrm{g} / \mathrm{d})$ : } \\
\hline 0 & 1.52 & $0 \cdot 66$ & $0 \cdot 86$ & 0.43 \\
\hline 200 & 1.75 & 0.76 & 0.99 & 0.44 \\
\hline 400 & 2.00 & 0.94 & 1.06 & 0.47 \\
\hline 600 & 1.89 & 0.97 & 0.92 & 0.51 \\
\hline Glucose: $800 \mathrm{~g} / \mathrm{d}$ & 1.64 & 0.55 & 1.09 & 0.34 \\
\hline SE of differencest & 0.07 & 0.05 & $0 \cdot 05$ & 0.02 \\
\hline \multicolumn{5}{|l|}{ Statistical significance: } \\
\hline Treatment effects $\dagger$ & $* *$ & $* *$ & * & $* *$ \\
\hline Linear trends $\dagger$ & $* * *$ & $* * *$ & NS & $* *$ \\
\hline Quadratic trends $\dagger$ & $*$ & NS & $* *$ & NS \\
\hline
\end{tabular}

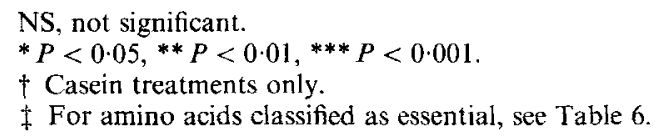

Total AA concentrations in plasma increased significantly with each level of casein up to $400 \mathrm{~g} / \mathrm{d}(P<0.01)$ and then declined, as indicated by the significant quadratic effect $(P<0.05$, Table 5). Examination of the separate totals for EAA and non-essential AA showed that the quadratic effect was confined to the non-essential AA. The ratio, EAA: total AA also increased significantly in progressing from zero-casein infusion to $600 \mathrm{~g} / \mathrm{d}$ $(P<0.01$, Table 5).

The effects of abomasal infusion of casein and of glucose on the concentrations of individual AA in plasma are given in Table 6. With the exception of threonine which showed a small decrease, the concentration of all EAA increased in response to additions of casein. The concentrations of methionine in plasma were low at all levels of casein addition and on six separate occasions were below the minimum detection limit of the analytical equipment (approximately $6 \mathrm{nmol} / \mathrm{ml}$ ): for one animal (the highest milk producer), methionine was detected in plasma only at the $600 \mathrm{~g}$ casein $/ \mathrm{d}$ level. For the purpose of statistical analysis these missing values were replaced with the minimum value of $6 \mathrm{nmol} / \mathrm{ml}$, hence the values given for methionine in Table 6 must be considered maximum values and the standard errors quoted must be treated with caution.

The proportionate increases in non-essential AA were least for glutamic acid and serine and greatest for proline. Glycine showed little change over the first two levels of casein addition but decreased significantly at the $600 \mathrm{~g} / \mathrm{d}$ level. As noted previously for methionine, cysteine concentrations tended to be low on the zero-casein treatment and for the highest yielding animal was below the limit of detection (approximately $12 \mathrm{nmol} / \mathrm{ml}$ ) on this treatment and when the glucose infusion was given. The minimum detection value was again inserted for the purpose of statistical analysis. 
Table 6. Mean concentrations (nmol/ml) of individual amino acids $(A A)$ in jugular plasma of lactating cows given abomasal infusions of casein or glucose

(Each value is the mean of four observations, each of which represented a composite of seven separate samples obtained over a $24 \mathrm{~h}$ period)

\begin{tabular}{|c|c|c|c|c|c|c|c|c|}
\hline \multirow[b]{3}{*}{ Treatment } & \multirow[b]{3}{*}{0} & \multirow{2}{*}{\multicolumn{3}{|c|}{ Casein $(\mathrm{g} / \mathrm{d})$}} & \multirow{3}{*}{$\begin{array}{c}\begin{array}{c}\text { Glucose } \\
(\mathrm{g} / \mathrm{d})\end{array} \\
800\end{array}$} & \multirow{3}{*}{$\begin{array}{c}\text { SE of } \\
\text { difference } \dagger\end{array}$} & \multicolumn{2}{|c|}{$\begin{array}{c}\text { Statistical } \\
\text { significance }\end{array}$} \\
\hline & & & & & & & \multirow{2}{*}{$\begin{array}{c}\text { Treatment } \\
\text { effects }{ }^{\dagger}\end{array}$} & \multirow{2}{*}{$\begin{array}{l}\text { Linear } \\
\text { trends }\end{array}$} \\
\hline & & 200 & 400 & 600 & & & & \\
\hline \multicolumn{9}{|l|}{ Essential AA: } \\
\hline Methionine & $<8.0$ & $<9.5$ & $<16 \cdot 2$ & $13 \cdot 5$ & $<12 \cdot 5$ & $(2 \cdot 23) \ddagger$ & $*$ & $*$ \\
\hline Phenylalanine & $43 \cdot 5$ & $40 \cdot 3$ & $50 \cdot 2$ & $47 \cdot 2$ & $45 \cdot 0$ & $2 \cdot 90$ & $\mathrm{NS}+$ & $\mathrm{NS}+$ \\
\hline Histidine & 57.8 & $70 \cdot 0$ & $85 \cdot 0$ & $64 \cdot 2$ & $48 \cdot 2$ & $7 \cdot 48$ & $*$ & NS \\
\hline Tyrosine & $27 \cdot 0$ & $30 \cdot 2$ & $35 \cdot 8$ & $37 \cdot 8$ & $29 \cdot 5$ & $2 \cdot 44$ & $*$ & $* *$ \\
\hline Threonine & $78 \cdot 2$ & $77 \cdot 0$ & $70 \cdot 5$ & $70 \cdot 0$ & $85 \cdot 8$ & $6 \cdot 30$ & NS & NS \\
\hline Valine & 111.8 & $147 \cdot 0$ & $186 \cdot 8$ & $248 \cdot 0$ & $77 \cdot 2$ & $15 \cdot 70$ & $* * *$ & $* * *$ \\
\hline Leucine & $65 \cdot 8$ & $84 \cdot 0$ & $104 \cdot 2$ & $141 \cdot 5$ & $49 \cdot 2$ & $8 \cdot 76$ & $* * *$ & $* * *$ \\
\hline Isoleucine & 78.8 & $87 \cdot 5$ & $100 \cdot 0$ & $111 \cdot 2$ & $40 \cdot 0$ & $10 \cdot 37$ & $\mathrm{NS}+$ & $*$ \\
\hline Lysine & $84 \cdot 2$ & $102 \cdot 2$ & $120 \cdot 5$ & 126.0 & $70 \cdot 2$ & $12 \cdot 69$ & $\mathrm{NS}+$ & * \\
\hline Arginine & $101 \cdot 5$ & $108 \cdot 8$ & $127 \cdot 2$ & $112 \cdot 2$ & $85 \cdot 2$ & $32 \cdot 01$ & NS & NS \\
\hline \multicolumn{9}{|l|}{ Non-essential AA: } \\
\hline Glutamic & $160 \cdot 2$ & $179 \cdot 0$ & $180 \cdot 2$ & $148 \cdot 5$ & $156 \cdot 2$ & $7 \cdot 78$ & $*$ & NS \\
\hline Aspartic & $11 \cdot 0$ & $15 \cdot 5$ & $16 \cdot 0$ & $17 \cdot 8$ & $15 \cdot 0$ & $2 \cdot 02$ & $\mathrm{NS}+$ & $*$ \\
\hline Alanine & 190.8 & 211.8 & $235 \cdot 0$ & $217 \cdot 8$ & $214 \cdot 7$ & $18 \cdot 20$ & NS & NS \\
\hline Cysteine & $<16.5$ & $21 \cdot 8$ & $26 \cdot 5$ & $26 \cdot 2$ & $<18.0$ & $(3 \cdot 06) \ddagger$ & NS+ & $* *$ \\
\hline Proline & $62 \cdot 8$ & $102 \cdot 2$ & $170 \cdot 8$ & $143 \cdot 5$ & $78 \cdot 7$ & $37 \cdot 40$ & NS & $*$ \\
\hline Serine & 91.0 & $104 \cdot 2$ & $102 \cdot 2$ & $95 \cdot 2$ & $132 \cdot 0$ & $6 \cdot 67$ & NS & NS \\
\hline Glycine & $335 \cdot 2$ & $350 \cdot 8$ & $327 \cdot 5$ & $268 \cdot 2$ & 483.2 & $16 \cdot 05$ & $* *$ & $* *$ \\
\hline
\end{tabular}

NS, not significant; NS,$+ P<0 \cdot 1$.

${ }^{*} P<0.05,{ }^{* *} P<0.01,{ }^{* * *} P<0.001$.

$\dagger$ Casein treatments only.

$\ddagger$ Approximate SE, see p. 547.

\section{Rumen VFA}

The samples of rumen fluid obtained for VFA analysis in periods 3 and 4 showed no significant differences due to dietary treatment and only minor differences between animals. The mean molar proportions of the individual VFA present in the eight samples were acetic acid 0.69 (SE 0.01), propionic acid 0.18 (SE 0.004), butyric acid 0.12 (SE 0.007), branched-chain and higher acids 0.02 (SE 0.002).

\section{Period effects and metabolic interrelations}

It was expected that some of the indices examined would show considerable changes with time-period on account of the changes in the pattern of milk production which occur during the early weeks of lactation. This was particularly true of the energy retention values, noted previously, for which the period effect was such that all cows, irrespective of treatment, were in negative energy balance in period 1 and all were in positive energy balance in period 4 $(P<0.001)$. This obviously reflected changes with time after parturition in the extent of body tissue mobilization and it was notable that almost all other measures showing major period effects were those which were influenced in some way by the metabolism of body fat. Thus the respiratory quotient (RQ) increased progressively $(P<0.001)$ from 1.08 in 
Table 7. Mean retentions of nitrogen $(\mathrm{g} / \mathrm{d})$ and energy $(M J / d)$ and the estimated mobilization of body protein and fat in lactating cows given abomasal infusions of casein

(Each value is the mean of four observations)

\begin{tabular}{|c|c|c|c|c|c|c|}
\hline \multirow[b]{3}{*}{ Treatment } & \multirow{2}{*}{\multicolumn{2}{|c|}{ Retention }} & \multicolumn{4}{|c|}{ Body tissue balance } \\
\hline & & & \multicolumn{2}{|c|}{ Protein } & \multicolumn{2}{|c|}{ Fat } \\
\hline & $N(g / d)$ & Energy $(\mathrm{MJ} / \mathrm{d})$ & $(\mathrm{MJ} / \mathrm{d})$ & $(g / d) \dagger$ & $(\mathrm{MJ} / \mathrm{d})$ & $(g / d) \dagger$ \\
\hline \multicolumn{7}{|l|}{ Casein $(\mathrm{g} / \mathrm{d})$ : } \\
\hline 0 & $-20 \cdot 3$ & $-6 \cdot 3$ & -2.98 & -127 & $-3 \cdot 34$ & -85 \\
\hline 200 & $-14 \cdot 3$ & $-12 \cdot 8$ & $-2 \cdot 10$ & -89 & $-10 \cdot 75$ & -272 \\
\hline 400 & $-1 \cdot 0$ & $-11 \cdot 4$ & $-0 \cdot 15$ & -6 & $-11 \cdot 29$ & -286 \\
\hline 600 & $6 \cdot 8$ & -7.9 & +1.00 & 42 & -8.92 & -226 \\
\hline SE of differences & $7 \cdot 28$ & $5 \cdot 20$ & 1.07 & $45 \cdot 5$ & 5.09 & $128 \cdot 8$ \\
\hline \multicolumn{7}{|l|}{ Statistical significance: } \\
\hline Treatment effects & $*$ & NS & $*$ & $*$ & NS & NS \\
\hline Linear trends & $* *$ & NS & $*$ & * & NS & NS \\
\hline
\end{tabular}

NS, not significant.

${ }^{*} P<0.05,{ }^{* *} P<0.01$.

$\uparrow$ Energy values of body protein and fat taken as 23.5 and $39.5 \mathrm{~kJ} / \mathrm{g}$ respectively.

period 1 to 1.20 in period 4 . FCM yield decreased from period 1 to period $4(P<0.01)$ as did the fat content of milk $(P<0.05)$ and the daily yields of fat and energy in milk $(P<0.01)$. Daily heat production also decreased significantly over the duration of the experiment $(P<0.01)$ and it is of interest that heat production was significantly correlated with the quantity of body fat mobilized $(r 0.78, P<0.01)$ but was not significantly related to $\mathrm{ME}$ intake.

Of the various plasma constituents examined only $\mathrm{GH}$ showed a significant trend with time, decreasing from period 1 to period $4(P<0.05)$. The concentration of NEFA in plasma showed a similar trend $(P<0 \cdot 10)$ and for this metabolite a highly significant inverse relation was observed between the concentration in plasma and energy retention when energy retention values were negative but no such relation was apparent when energy retention was positive. Insulin: $\mathrm{GH}$ was not significantly correlated with any other plasma constituents nor with any measures of energy retention or milk yield.

The observed values for $\mathbf{N}$ and energy retention and the calculated quantities of body protein and fat mobilized on each treatment are shown in Table 7 . On the zero-casein treatment the catabolism of body protein accounted for 0.47 of total energy lost but this decreased to 0.16 with the first addition of casein. In contrast, body fat mobilization increased threefold in response to the infusion of $200 \mathrm{~g}$ casein. At the $400 \mathrm{~g}$ casein/d level body fat mobilization showed a further increase whereas a decrease in fat mobilization and a deposition of body protein was seen at the highest level of casein infusion.

\section{DISCUSSION}

The basal level of feeding adopted for the present study was designed to provide only sufficient $\mathrm{N}$ and energy for the daily production of $10 \mathrm{~kg}$ milk. Based on the milk yields actually achieved and current estimates of requirements the intakes of $\mathrm{N}$ supplied $0 \cdot 84,0 \cdot 95$, 1.13 and 1.28 of the tissue N (TN) requirements (Agricultural Research Council, 1984) on 
the $0,200,400$ and $600 \mathrm{~g}$ casein/d treatments respectively. The corresponding values for $\mathrm{ME}$ intake as a proportion of requirement (Agricultural Research Council, 1980) were 0.85, $0 \cdot 80,0.83$ and 0.83 .

\section{Yields of milk and milk constituents}

The increases in milk yield and in milk $\mathrm{N}$ and fat yield in response to graded additions of casein were similar to those described by Ørskov et al. (1977) for cows in early lactation given casein infusions of 250,500 or $750 \mathrm{~g} / \mathrm{d}$. In both experiments the greatest increase in each of these measurements occurred in response to the first addition of casein (200 or $250 \mathrm{~g} / \mathrm{d}$ ) and in both there was evidence that the yields of milk or FCM reached maximum values at the higher levels of casein addition. In the present work this 'plateau' position was reached at about $400 \mathrm{~g} / \mathrm{d}$ casein whereas in the work of Ørskov et al. (1977) it appeared to be between 500 and $750 \mathrm{~g} / \mathrm{d}$. In a similar trial with two cows in early lactation, Istasse (1984) found milk yields to increase linearly with levels of casein infusion up to $1010 \mathrm{~g} / \mathrm{d}$ although FCM yield reached a maximum at $670 \mathrm{~g} / \mathrm{d}$. In the only other studies in which more than one level of casein has been given to cows in early lactation neither Trigg et al. (1983) nor König et al. (1984) could detect a further increase in milk yield when casein infusion was increased beyond 200 or $240 \mathrm{~g} / \mathrm{d}$ respectively; in both these experiments, however, the daily intakes of $\mathrm{N}$ and energy from the basal feed appeared to be close to the animals' requirements for the milk production achieved.

In common with most other reports (Clark, 1975), infusion of casein in this experiment increased both milk $\mathrm{N}$ concentration and daily $\mathrm{N}$ yield and in both the present study and that of Ørskov et al. (1977) these effects persisted through to the highest level of casein addition. However, although daily yields of milk fat increased, the finding that casein infusion also caused a significant increase in milk fat concentration (Ørskov et al. 1977) was not confirmed in the present work.

Although the effects of glucose infusion on milk yield in this experiment could not be fully cornpared with the effects of casein, a more limited statistical analysis, in which period effects were ignored, showed that the yields of milk, FCM, fat and $\mathrm{N}$ obtained with glucose did not differ from those obtained on the zero-casein treatment but were significantly lower $(P<0.05)$ than those seen when casein infusions were given. This confirms many other reports in which glucose, in contrast to casein, has failed to promote an increase in milk synthesis (Clark, 1975; Clark et al. 1977; Ørskov et al. 1977; Oldham et al. 1984). It is evident also that the absence of response to glucose cannot be explained in terms of its effect on insulin concentrations as suggested by MacRae (1983) or on insulin-GH interactions (Bines $\&$ Hart, 1982) since the levels and ratios of these hormones in plasma differed only slightly between the glucose and $600 \mathrm{~g} / \mathrm{d}$ casein treatments (Table 4) while the corresponding milk yields differed by $4.9 \mathrm{~kg} / \mathrm{d}$ (Table 1 ).

\section{Energy metabolism}

As noted previously, the intake of energy from the diet and infused casein was such that there was a fairly uniform deficiency of energy on all treatments. Although the observed energy retention values did not differ significantly between treatments (Table 3 ) there was sufficient circumstantial evidence (p. 545) to suggest that real differences existed between the zero-casein treatment and the others. Moreover, when calculated in terms of the separate components of protein and fat in the mobilized tissue (Table 7) the results indicated that the initial infusion of casein resulted in a threefold increase in the amount of fat withdrawn from body stores. These findings thus support the suggestions of Ørskov et al. (1977) that casein infusions act in part by stimulating the release of fat from adipose tissue.

Evidence from feeding trials that an increase in dietary protein can stimulate the 
mobilization of body fat in lactating ewes (Robinson et al. 1974, 1979) could not be confirmed in comparative slaughter studies in which ewes in early lactation were given diets containing fish meal to supply crude protein $(\mathrm{N} \times 6.25)$ concentrations of either 116 or $143 \mathrm{~g} / \mathrm{kg}$ (Cowan et al. $1981 \mathrm{~b}$ ). In these studies the total loss of body fat over a $35 \mathrm{~d}$ period did not differ between treatments although milk yields were significantly increased. On the basis of these and earlier findings (Cowan et al. 1980) the authors concluded that the increased milk production resulting from additional protein intake was due to an increase in the efficiency of energy utilization (Cowan et al. 1981 b).

In the present work, when milk-energy yield was corrected for changes in body tissue, there was no evidence that the efficiency of utilization of dietary ME for lactation was influenced by the provision of supplementary protein as casein (Fig. 2). Similar findings regarding the effects of protein level on energy utilization in lactating cows have been reported by Tyrrell \& Moe (1980) and by Vermorel et al. (1983). The regression coefficient of 0.84 obtained in the present analysis (Fig. 2) is puzzling since it indicates an efficiency of utilization of dietary ME for lactation equivalent to that attributable to mobilized body fat (Moe et al. 1971). Two suggestions can be offered to account for this high value: first, the factor of 0.84 adopted for the partial efficiency of conversion of body fat to milk energy might be an underestimate in the present context and would thereby inflate the estimate for partial efficiency of dietary ME utilization and, second, the increments in ME, indicated on the abscissa of Fig. 2, are derived almost entirely from casein infused into the abomasum. Casein administered in this way to sheep was used for the maintenance of body tissues with an efficiency of 0.80 (Martin \& Blaxter, 1961); nothing is known of the corresponding efficiency of casein for the synthesis of milk constituents but it could well be equally high in cows restricted in energy intake in early lactation. Kronfeld (1976) has calculated the theoretical maximum efficiencies of synthesis of milk constituents and has quoted values of 0.84 to 0.87 for the formation of milk proteins from mixed AA and 0.71 to 0.98 for milk-fat synthesis, the higher value representing its formation from palmitate and propionate precursors. Thus high efficiency factors could occur when large amounts of body fat are mobilized or, as demonstrated by Kronfeld et al. (1980), when the diet contains a high proportion of protected tallow.

\section{$N$ metabolism}

As indicated earlier, $\mathrm{N}$ intakes relative to requirements covered the spectrum from a moderate deficit on the basal diet to a considerable excess at the highest level of casein infusion. The changing pattern of $\mathrm{N}$ utilization under these circumstances is clearly illustrated by the values for $N$ retention (Table 2) and by the changes in plasma concentrations of nitrogenous metabolites (Tables 4 and 5). Thus plasma urea concentrations increased only when casein infusion exceeded $400 \mathrm{~g} / \mathrm{d}$ and $\mathrm{N}$ retention values became positive, and this was associated also with a marked increase in urinary $\mathrm{N}$ excretion. An increased oxidation of AA to urea at the highest level of casein supplementation is also evident from the plasma AA values (Table 5), as is an apparent preferential utilization of EAA for milk-protein formation at the lower levels of $\mathrm{N}$ intake and of the non-essential AA for oxidation under conditions of adequate $\mathrm{N}$ supply.

Regression analysis (Fig. 1) of net productive $\mathrm{N}$ on total $\mathrm{N}$ intake showed no difference in efficiency of $\mathrm{N}$ utilization with increasing $\mathrm{N}$ intake. The regression coefficient in this relation cannot however be compared directly with the efficiency values adopted in current schemes of $\mathrm{N}$ evaluation in ruminants (Agricultural Research Council, 1984) since it is based on total $\mathrm{N}$ intake rather than on $\mathrm{AA}-\mathrm{N}$ available for absorption. However, by using the values for RDN and UDN content of the diet given on p. 539, the actual ME intakes observed, the factor of 0.8 for the proportion of AA-N in microbial protein (Agricultural 
Research Council, 1984) and the assumption that the total $\mathrm{N}$ of casein is AA-N we can obtain an estimate of total AA-N reaching the duodenum.

When this estimate of $\mathrm{AA}-\mathrm{N}$, expressed as $\mathrm{mg} \mathrm{N} / \mathrm{kg}$ body-weight ${ }^{0.25}$ per $\mathrm{d}$, was used rather than total $\mathrm{N}$ intake as the independent variable $(X)$ in the relation shown in Fig. 1, the resulting regression equation was

$$
Y=0.65(\mathrm{SE}, 0.06) X-436, \quad(\mathrm{RSD} 73.5, P<0.001) \text {. }
$$

Thus the estimated efficiency of utilization of duodenal AA-N for productive purposes in this experiment was 0.65 and was obviously comparable with the product of the factors 0.85 and 0.80 adopted by the Agricultural Research Council (1984) for the true digestibility of $\mathrm{AA}-\mathrm{N}$ in the small intestine and the efficiency of utilization of absorbed AA-N respectively.

The $\mathrm{N}$ lost from the body on the basal diet amounted to $20.3 \mathrm{~g} / \mathrm{d}$. Expressed as a net fractional rate of loss of body protein (Oldham \& Lindsay, 1983), when total body protein is taken as 0.15 of live weight (Reid et al. 1955), this $\mathrm{N}$ loss was equivalent to $0.0018 / \mathrm{d}$ and can be compared with a maximum loss rate of $0.001 / \mathrm{d}$ calculated from the findings of Cowan et al. (1981 a) for cows in early lactation given high- or low-protein diets. Botts et al. (1979) subjected cows in early lactation to an $\mathrm{N}$-depletion regimen in which intakes of $\mathrm{N}$ were restricted to $203 \mathrm{~g} / \mathrm{d}$, similar to the basal intake in the present work, for a period of 8-12 weeks. Mean loss of tissue $\mathrm{N}$ in fifteen cows was $17.4 \mathrm{~g} / \mathrm{d}$, a fractional loss rate of $0.0014 / \mathrm{d}$. Thus the rate of body protein catabolism on the basal diet in the present work was possibly close to the maximum attainable in cows, and similar values, ranging from 0.0017 to $0.0020 / \mathrm{d}$ can be calculated from slaughter values for lactating ewes given adequateor low-protein diets in early lactation (Cowan et al. 1979, 1981 b).

\section{Protein-energy interactions in the response to casein infusion}

Oldham (1984) has discussed protein-energy relations in the lactating cow in terms of the ratio, $\mathrm{AA}-\mathrm{N}: \mathrm{ME}$ in the nutrients absorbed from the gut and has suggested that the minimum requirement for the high-producing cow is close to $1.2 \mathrm{~g} \mathrm{AA}-\mathrm{N} / \mathrm{MJ} \mathrm{ME}$. The maximum value attainable by dietary manipulation is thought to be about $1.6 \mathrm{~g} / \mathrm{MJ}$ whereas the ratio in mobilized body tissue may range from a maximum of $1 \cdot 1 \mathrm{~g} / \mathrm{MJ} \mathrm{ME}$ to a more usual 0.2 g/MJ ME (Oldham \& Tamminga, 1980; Oldham, 1984). When viewed in relation to the ratio present in milk $(1.4-1.6 \mathrm{~g} / \mathrm{MJ} \mathrm{ME})$ there is obviously a need for an increased supply of AA-N from the gut when large amounts of body fat are mobilized in early lactation.

By applying the factor 0.85 for the true digestibility of AA (Agricultural Research Council, 1984) to the above estimates of AA-N reaching the duodenum, values of absorbed AA-N:ME in the present experiment were calculated to be $1 \cdot 12,1 \cdot 31,1.41$ and $1.61 \mathrm{~g} / \mathrm{MJ}$ for the $0,200,400$ and $600 \mathrm{~g} / \mathrm{d}$ levels of casein infusion respectively. These values thus span the complete range of dietary conditions discussed by Oldham (1984) and, when considered along with the information on body tissue mobilization given in Table 7, provide a basis on which the responses to successive additions of casein may be explained. Thus, on the basal dietary treatment total energy intake was deficient and AA-N:ME was borderline for milk production; the animal responded, however, by mobilizing a disproportionate amount of body protein relative to body energy $(3 \cdot 2 \mathrm{~g} \mathrm{~N} / \mathrm{MJ} \mathrm{ME}$, Table 7$)$ in an attempt to increase the dietary AA-N:ME value to that of milk. Since adequate stores of tissue lipids were available for mobilization (witness the increase in other treatment periods) the excessive catabolism of body protein stores suggests that the primary deficiency in this situation was of one or more EAA required for milk synthesis and possibly also for lipid transport. From the evidence cited above the rate of breakdown of tissue protein on this treatment would appear to be close to the maximum rate attainable and the low 
concentrations of AA in plasma, together with the low EAA: total AA value (Table 5), lend support to the suggestion of a deficiency in one or more EAA.

On the next treatment the infusion of casein with a high AA-N:ME value (6.6 g/MJ) improved the value for the mixture absorbed from the intestines and contributed enough of the deficient AA to allow further milk-protein synthesis. This in turn required additional energy and the animal was stimulated to mobilize body fat to match the enhanced supply of AA arising from dietary sources and from tissue catabolism. In this case, however, the ratio of $\mathrm{AA}-\mathrm{N}: \mathrm{ME}$ in the mobilized tissue remained within the normal range $(1 \cdot 1$, Table 7$)$ since there was sufficient non-essential AA-N available from the casein supplement to limit tissue $\mathrm{N}$ losses. With the increase in milk production the supply of EAA may again have reached a critical level but it seems likely that the ultimate limitation on milk secretion on this treatment was the supply of energy available from dietary sources and mobilized body tissue.

With a further addition of casein the dietary AA-N:ME became close to that of milk. The AA deficit was again corrected but the surplus AA stimulated only a small increase in body fat mobilization and in milk yield and sufficient $\mathrm{N}$ remained to correct the overall $\mathrm{N}$ balance. In this case milk secretion appeared to be limited by an energy deficit resulting from an inability to mobilize more body fat. Presumably this occurs because the animals have reached a ceiling in terms of their genetic capacity for lipolysis of adipose tissue or for the transport of the resulting fatty acids, to the extent that one or other of the enzyme systems involved in these reactions is working to capacity. A corollary to this is that animals of superior genetic merit for lactation would reach this set point at a higher absorbed AA-N:ME value, and this might explain the variability seen in the level of casein required for maximum lactational response (e.g. Orskov et al. 1977; Istasse, 1984).

On the highest level of casein supplementation excess $\mathbf{N}$ was available in relation to that required for milk synthesis. The excess AA given by infusion, particularly the non-essential AA, might be expected to be diverted towards gluconeogenesis and oxidation (Table 5) and would result presumably in an increase in glucose entry rate (Bassett \& Thornburn, 1971) and in insulin concentration (Table 4). Insulin then acts to partition energy away from milk secretion and into body tissue (Bauman \& Elliot, 1983), with an increased deposition of body protein (Table 7). As a consequence of a decreased transport of lipid, FCM yield would decline but with ample glucose available for lactose synthesis total milk yield might continue to rise (Table 1).

This proposed mechanism implies that increases in milk yield and milk-protein yield in response to casein (or limiting AA) will be seen only when sufficient energy is also available, either from labile body stores or from dietary sources. If adipose tissue is the only source available then there is the additional requirement that the physiological and endocrine status of the animal must favour the partition of nutrients towards the mammary gland (Bauman \& Elliot, 1983). The genetic potential of the animal will also play a part in determining the extent of body fat mobilization and may account, in genetically-superior animals, for increases in milk fat concentration as well as milk fat yield in some animals (Ørskov et al. 1977 ) or the eventual development of ketosis in others (Ørskov et al. 1981). In the absence of additional energy the response to casein infusion will be limited to the milk yield appropriate to the $\mathrm{N}$ and energy content of the infused protein; thus at the usual level of $400 \mathrm{~g} / \mathrm{d}$ the energy supplied as casein is sufficient for a yield of about $1.75 \mathrm{~kg}$ milk and this appears to be a common level of response in cows in mid-lactation (Clark et al. 1977) and is seen also in the experiments of Schwab et al. (1976) in which various mixtures of AA or casein alone were given by infusion into the abomasum.

An interesting illustration of these effects is seen in the work of Rulquin (1982) who examined the effects of two levels of energy intake $(0.85$ and $1 \cdot 10$ times requirement) and two levels of $\mathrm{N}$ intake ( 0.70 and 1.00 times requirement) in a factorial experiment with cows 
of declared moderate genetic potential in mid-lactation. The higher level of $\mathrm{N}$ intake was achieved by abomasal infusion of $500 \mathrm{~g}$ casein/d. When this casein was given at the low level of energy intake the increases in the yields of milk, protein and lactose were $1.4 \mathrm{~kg} / \mathrm{d}$, $99 \mathrm{~g} / \mathrm{d}$ and $47 \mathrm{~g} / \mathrm{d}$ respectively; when energy intake was increased by the intraruminal infusion of $23 \mathrm{MJ}$ of a high-propionate VFA mixture the corresponding increases in yield resulting from casein infusion were $3.5 \mathrm{~kg} / \mathrm{d}, 175 \mathrm{~g} / \mathrm{d}$ and $133 \mathrm{~g} / \mathrm{d}$. These animals were obviously unable to draw on body fat reserves to balance the additional $\mathrm{N}$ supplied as casein.

\section{Limiting $A A$}

The scheme detailed previously invokes a deficiency of one or more EAA to explain the primary response to casein infusion. Relative to plasma values reported in the literature (Derrig et al. 1974; Spires et al. 1975; Rulquin, 1983) the concentrations of several AA were low on the basal diet in the present work (Table 6) and this was particularly true of methionine and, to a lesser extent, of cysteine. Of these, methionine has long been regarded as potentially rate-limiting for milk production although unequivocal evidence of its ability to increase milk synthesis when given by infusion is still awaited (Mepham, 1982). Although the identification of limiting AA from plasma concentrations alone is open to question, the general indication that methionine was possibly limiting is attractive since it fits with the suggestion made by Oldham (1981) that methionine may also play a part in the regulation of lipid transport through its effect on lipoprotein synthesis (McCarthy et al. 1968). The protein-energy relations on the zero-casein treatment indicated that some inhibition of lipid mobilization might have occurred in conjunction with the enhanced protein catabolism and it is possible that a methionine deficiency was the causal agent in both conditions. In this regard Oldham (1984) has noted that where responses to dietary supplements of methionine or methionine hydroxyanalog have been seen in dairy cows these have tended to be as effects on milk fat concentration or yield, rather than on milk protein.

\section{Conclusions}

It is concluded from the foregoing discussion that under the dietary conditions imposed in the present study the primary response to infused casein was the correction of an AA deficit. Correction of this deficiency then allowed, or perhaps promoted, the mobilization of body fat stores to balance the high ratio of $\mathrm{AA}-\mathrm{N}$ : energy in the infused casein. The net effect was an increase in milk yield and this effect persisted until $\mathrm{N}$ equilibrium was achieved, after which the catabolism of excess protein resulted in a change in carbohydrate status and in endocrine status which favoured the deposition of body tissue at the expense of milk energy secretion. Most of these secondary effects appeared to depend on the protein : energy ratio of the absorbed nutrients rather than on unique attributes of casein per se.

The major question left unanswered is the mechanism whereby the provision of specific AA appears to stimulate the mobilization of body fat.

The authors are grateful to $\mathrm{Mr}$ W. A. C. McKelvey for surgery on the experimental animals and to Mr I. McDonald for statistical analysis. They wish to thank also Mr R. I. Smart and his colleagues for chemical analysis and Miss Maureen Annand and Mr D. S. Brown for the analysis of plasma samples. Mr G. Henderson of the North of Scotland College of Agriculture kindly undertook the assays of growth hormone in plasma.

\section{REFERENCES}

Agricultural Research Council (1980). The Nutrient Requirements of Ruminant Livestock. Farnham Royal, Slough: Commonwealth Agricultural Bureaux.

Agricultural Research Council (1984). The Nutrient Requirements of Ruminant Livestock, Suppl. no. I. Farnham Royal, Slough: Commonwealth Agricultural Bureaux. 
Bassett, J. M. \& Thornburn, G. D. (1971). Journal of Endocrinology 50, 59-74.

Bauman, D. E. \& Elliot. J. M. (1983). In Biochemistry of Lactation, pp. 437-468 [T. B. Mepham, editor]. Amsterdam: Elsevier.

Bines, J. A. \& Hart, I. C. (1982). Journal of Dairy Science 65, 1375-1389.

Blaxter, K. L., Brockway, J. M. \& Boyne, A. W. (1972). Quarterly Journal of Experimental Physiology 57, 60-72.

Blaxter, K. L. \& Martin, A. K. (1962). British Journal of Nutrition 16, 397-407.

Botts, R. L., Hemken, R. W. \& Bull, L. S. (1979). Journal of Dairy Science 62, 433-440.

Brouwer, E. (1965). In Energy Metabolism: Proceedings of 3rd Symposium on Energy Metabolism, Troon, EAAP Publication no. 11, p. 441 [K. L. Blaxter, editor]. London: Academic Press.

Clark, J. H. (1975). Journal of Dairy Science 58, 1178-1197.

Clark, J. H., Spires, H. R., Derrig, R. G. \& Bennink, M. R. (1977). Journal of Nutrition 107, 631-644.

Cowan, R. T., Reid, G. W., Greenhalgh, J. F. D. \& Tait, C. A. G. (1981 a). Journal of Dairy Research 48, 201-212.

Cowan, R. T., Robinson, J. J., Greenhalgh, J. F. D. \& McHattie, I. (1979). Animal Production 29, 81-90.

Cowan, R. T., Robinson, J. J., McDonald, I. \& Smart, R. I. (1980). Journal of Agricultural Science, Cambridge 95, 497-514.

Cowan, R. T., Robinson, J. J., McHattie, I. \& Pennie, K. (1981 b). Animal Production 33, 111-120.

Davidson, J., Mathieson, J. \& Boyne, A. W. (1970). Analyst 95, 181-193.

Derrig, R. G., Clark, J. H. \& Davis, C. L. (1974). Journal of Nutrition 104, 15I-159.

Farhan, S. M. A. \& Thomas, P. C. (1977). Proceedings of the Nutrition Society 36, 57A.

Gaines, W. L. \& Overman, O. R. (1938). Journal of Dairy Science 21, 261-271

Galbraith, H. \& Chesworth, J. M. (1977). Laboratory Practice 26, 471-472.

Gow, C. B., Ranawana, S. S. E., Kellaway, R. C. \& McDowell, G. H. (1979). British Journal of Nutrition 41, 371-382.

Istasse, L. (1984). The effect of method of feeding and type of feed on ruminant digestion and host animal metabolism. PhD Thesis, University of Aberdeen.

König, B. A., Oldham, J. D. \& Parker, D. S. (1984). British Journal of Nutrition 52, 319-328.

Kronfeld, D. S. (1976). Advances in Animal Physiology and Animal Nutrition 7, 5-26.

Kronfeld, D. S., Donoghue, S., Naylor, J. M., Johnson, K. \& Bradley, C. A. (1980). Journal of Dairy Science 63, $545-552$.

Ling, E. R. (1944). A Textbook of Dairy Chemistry, 2nd ed., vol. 2. London: Chapman and Hall.

McCarthy, R. D., Porter, G. A. \& Griel, L. C. (1968). Journal of Dairy Science 51, 459-462.

MacLeod, N. A., Corrigall, W., Stirton, R. A. \& Ørskov, E. R. (1982). British Journal of Nutrition 47, $547-552$.

MacRae, J. C. (1983). In Recent Advances in Animal Nutrition in Australia, pp. 23-34 [D. J. Farrell and Pran Vohra, editors]. Armidale: University of New England Publishing Unit.

Marsh, W. H., Fingerhut, B. \& Miller, H. (1965), Clinical Chemistry 11, 624-627.

Martin, A. K. \& Blaxter, K. L. (1961). Proceedings of the 2nd International Symposium on Energy Metabolism, EAAP Publication no. 10 , pp. 200-210.

Mepham, T. B. (1982). Journal of Dairy Science 65, 287-298.

Ministry of Agriculture, Fisheries and Food (1975). Energy Allowances and Feeding Systems for Ruminants, Technical Bulletin no. 33. London: H.M. Stationery Office.

Moe, P. W., Tyrell, H. F. \& Flatt, W. P. (1971). Journal of Dairy Science 54, 548-553.

Oldham, J. D. (1981). In Recent Developments in Ruminant Nutrition, pp. 49-81 [W. Haresign and D. J. A. Cole, editors]. London: Butterworths.

Oldham, J. D. (1984). Journal of Dairy Science 67, 1090-1114.

Oldham, J. D., Bines, J. A. \& MacRae, J. C. (1984). Proceedings of the Nutrition Society 43, 65A.

Oldham, J. D. \& Lindsay, D. M. (1983). Proceedings of the IVth International Symposium on Protein Metabolism and Nutrition, Clermont-Ferrand, France.

Oldham, J. D. \& Tamminga, S. (1980). Livestock Production Science 7, 437-452.

Ørskov, E. R., Grubb, D. A. \& Kay, R. N. B. (1977). British Journal of Nutrition 38, 397-405.

Ørskov, E. R., Reid, G. W., Holland, S. M., Tait, C. A. G. \& Lee, N. H. (1983). Animal Feed Science and Technology 8, 247-257.

Orskov, E. R., Reid, G. W. \& McDonald, I. (1981). British Journal of Nutrition 45, 547-555.

Ottenstein, D. M. \& Bartley, D. A. (1971). Journal of Chromatographic Science 9, 673-681.

Palmer, D. W. \& Peters, J. T. (1969). Clinical Chemistry 19, 891-901.

Ranawana, S. S. E. \& Kellaway, R. C. (1977a). British Journal of Nutrition 37, 67-79.

Ranawana, S. S. E. \& Kellaway, R. C. (1977b). British Journal of Nutrition 37, 395-402.

Reid, J. T., Wellington, G. H. \& Dunn, H. O. (1955). Journal of Dairy Science 38, 1344-1359.

Robinson, J. J., Fraser, C., Gill, J. C. \& McHattie, I. (1974). Animal Production 19, 331-339.

Robinson, J. J., McHattie, I., Calderon-Cortez, F. \& Thompson, J. L. (1979). Animal Production 29, $257-269$.

Rulquin, H. (1982). Reproduction, Nutrition Developpment 22, 905-921.

Rulquin, H. (1983). Reproduction, Nutrition Developpment 23, 1029-1042.

Schlenk, M. \& Gellerman, J. (1960). Analytical Chemistry 32, 1412-1414.

Schwab, C. G., Satter, L. D. \& Clay, A. B. (1976). Journal of Dairy Science 59, 1254-1270.

Sparrow, R. C., Hemken, R. W., Jacobsen, D. R., Button, F. S. \& Enlow, C. M. (1973). Journal of Dairy Science 56, 664. Abstr. 
Spires, H. R., Clark, J. H., Derrig, R. G. \& Davis, C. L. (1975). Journal of Nutrition 105, 1111-1121.

Trigg, T. E., Parr, C. R., Day, A. M. \& Parsons, B. W. (1983). In Energy Metabolism of Farm Animals, EAAP Publication no. 29, pp. 42-45 [A. Akern and F. Sundstøl, editors]. Ski, Norway: Informasjonsteknikk A/S.

Trinder, P. (1969). Annals of Clinical Biochemistry 6, 24-27.

Tyrrell, H. F. \& Moe, P. W. (1980). In Energy Metabolism, pp. 311-313 [L. E. Mount, editor]. London: Butterworths.

Vermorel, M., Remond, B., Vernet, J. \& Liamadis, D. (1983). In Energy Metabolism of Farm Animals, EAAP Publication no. 29, pp. 18-21 [A. Akern and F. Sundstøl, editors]. Ski, Norway: Informasjonsteknikk A/S.

Whitelaw, F. G., Milne, J. S., Ørskov, E. R. \& Smith, J. S. (1985). Proceedings of the Nutrition Society 44, 44A.

Zivin, J. A. \& Snarr, J. F. (1973). Analytical Biochemistry 52, 456-461. 